\title{
ETHICAL DISPUTES OVER LIVING ORGAN TRANSPLANT AND THE APPLICABLE SOLUTIONS TO THESE DISPUTES IN CHINA ${ }^{1}$
}

\author{
Tongwei Yang ${ }^{2}$, Yijin Wu ${ }^{3}$
}

\begin{abstract}
Objectives: In this study, we examine the ethical issues concerning living organ transplant in China. We attempt to review and analyze the ethical disputes that the living organ transplant faces in China and try to find applicable solutions to these disputes. Design: Ethical Analysis. Setting: Living organ transplant in China. Results: The ideal approaches to solving the ethical disputes involve (1) preventing disease, strengthening physical fitness, and improving the health of the national citizen; (2) encouraging the citizens to donate their organs after death; and (3) developing new technologies for organ transplant. Realistic approaches to addressing the ethical disputes over the living organ transplant include choosing the lesser of two evils, reducing the harm to the donor as much as possible and improving the transplant quality. Conclusions: The living organ transplant in China is an expedient measure instead of an ideal option and should be conducted under strict laws and regulations.
\end{abstract}

Key words: living organ transplant; ethical disputes; organ donors; organ recipients

Disputas éticas sobre el trasplante de órganos vivos y soluciones aplicables a esta disputas en China

Resumen: Objetivos: En este estudio examinamos los temas éticos respecto del trasplante de órganos vivos en China. Revisamos y analizamos las disputas éticas que enfrenta el trasplante de órganos vivos en China y tratamos de encontrar soluciones aplicables a estas disputas. Diseño: Análisis ético. Configuración: Trasplante de órganos vivos en China. Resultados: Las aproximaciones ideales para resolver las disputas éticas incluyen (1) prevenir la enfermedad, fortalecer el estado físico y mejorar la salud del ciudadano; (2) animar a los ciudadanos a donar sus órganos después de la muerte, y (3) desarrollar nuevas tecnologías para el trasplante de órganos. Entre las aproximaciones realistas para abordar las disputas éticas sobre el trasplante de órganos vivos se encuentra elegir el mal menor, reduciendo el daño al donante cuanto sea posible y mejorando la calidad del trasplante. Conclusiones: El trasplante de órganos vivos en China es una medida conveniente más que una opción ideal y debería realizarse bajo estrictas leyes y regulaciones.

Palabras clave: trasplante de órganos vivos, disputas éticas, donantes de órganos, receptores de órganos

Disputas éticas sobre transplante de órgáos vivos e as soluçóes aplicáveis a estas disputas na China

Resumo: Objetivos: Neste estudo, examinamos as questôes éticas relativas ao transplante de órgáos vivos na China. Vamos tentar rever e analisar os conflitos éticos que o transplante de órgãos vivos enfrenta na China e tentar encontrar soluções aplicáveis a estas disputas. Projeto: Análise ética. Configuração: Transplante de órgão vivo na China. Resultados: As abordagens ideais para resolver os conflitos éticos envolvem (1) prevenção de doenças, fortalecimento da aptidão física e melhora da saúde do cidadão nacional; (2) incentivar os cidadãos a doar seus órgãos após a morte; e (3) desenvolvimento de novas tecnologias para transplante de órgão. Abordagens realistas para enfrentar as disputas éticas sobre o transplante de órgão vivos incluem escolher o menor de dois males, reduzindo o dano ao doador o máximo possível e melhorar a qualidade do transplante. Conclusóes: Transplantes de órgãos vivos na China é uma medida conveniente ao invés de uma opção ideal e deve ser conduzida sob estritas leis e regulamentos.

Palavras-chave: transplante de órgãos vivos, conflitos éticos, doadores de órgãos, destinatários do órgão

\footnotetext{
${ }^{1}$ The research was funded by a grant (16CZXJ01) from Shandong Social Science Research Council.

${ }^{2}$ School of Medicine, Shandong University, China

${ }^{3}$ School of Translation Studies/Center for Medical Humanities in the Developing World, Qufu Normal University, China

Correspondence: wuyijin9972@126.com
} 


\section{Introduction}

The organ transplant technology is known as the frontier of medicine in the 21 st century. As the most effective method for treating the end-stage organ failure, organ transplant has revitalized many critically ill patients. Currently, there are a large number of patients waiting for kidney, heart and lung transplant in China(1). In recent years, China has been increasing fund for clinical research on organ transplant. Also, the ethical issues on organ transplant has drawn much attention from both ethicists and transplant professionals. In 2000, Chen Zhonghua started to perform the living organ transplant in China and proposed two strategies to facilitate living organ donation, that is, home self-rescue and mutual rescue between families. In 2004, the proportion of living organ transplant in organ transplant was only $0.32 \%$ and increased to $24.7 \%$ in 2007 (2). Researchers propose that living organ transplant has a good number of advantages. For example, liver is an organ with high regenerative capacity; specifically, after living organ transplant, the partial livers of both the donor and recipient will grow and remodel to form complete organs. In terms of the survival rate and transplant rejection, the living organ transplant is more felicitous than the cadaveric organ transplant. There are a great number of touching stories about living organ donation in China. For example, a father donates part of his liver to his son; a husband donates a kidney to his wife. However, there also exists questionable attitude toward the living organ transplant. For example, Shi (2016) argued that living organ transplant could cause an irreversible damage to the donor's body(3).

In this study, we attempt to review and analyze the ethical disputes that the living organ transplant faces in China and try to explore applicable solutions to these disputes.

\section{The Ethical Disputes over the Living Organ Transplant}

The complexity of social morality makes living organ transplant full of disputes. Some scholars show positive attitudes toward living organ donation, however, others express negative attitudes toward living organ donation. Here, we will ela- borate on the views of the opponents and proponents.

\section{The Viewpoints of the Opponents}

Zhang Zanning and Zhu Wei are two representatives who are against the living organ transplant in China. Zhang (2006) proposed four reasons for opposing the living organ transplant. First, procuring organs from living donors is not humanistic at all(4). Living organ transplant violates one of the basic principles of medical ethics - "non-harmfulness" because living organ transplant has not reached the ideal security level and the harm to donors weigh against the benefits recipients acquire. Thus, the living organ donation has been prohibited by a number of countries in the world. Second, the living organ donation violates the existing law. Article 98 of the General Provisions of Civil Law of the People's Republic of China stipulates that every citizen has the right to enjoy his/her good health. It indicates that no one is supposed to seek his or her personal gain at the expense of harming another. Also, China's existing law stipulates that the act that causes the total or partial loss of important organs should be seen as "serious injury" and the act that causes the loss of functional organs should be considered as "minor injury". Third, people should keep calm in the face of death and medical science shouldn't interfere in human beings' lives excessively. Finally, once law regarding the living organ donation is enacted, potential organ recipients will feel doom and gloom mentality.

Zhu (2006) argued that: (1) living organ transplant doesn't make any sense because the riskbenefit ratio of the transplant isn't equal for donors and recipients; the donor undertakes the risks while the recipient gains the benefit; (2) it is unknown to what extent donors are willing to donate their organs of their own will rather than catering to their family's interest(5).

\section{The Viewpoints of the Proponents}

Based on a detailed review of previous studies, this study concludes four main reasons why living organ transplant has been supported. First, China has made great progress in organ transplant and the techniques for living organ transplant have 
become more and more mature. From the medical point of view, the cold ischemia time for the living organ is relatively short and thus delayed transplant function rarely occurs. In this sense, the risk of the acute rejection is relatively low and thus the survival rate for recipients is high. Due to the higher matching rate and better compatibility of organs or tissues between two genetically related people, the transplant rejection can be reasonably inhibited, the dose of anti-rejection drugs taken by the recipient can be relatively reduced, and thus the adverse effects on the recipients'body caused by immunosuppressant drugs can be mi$\operatorname{nimized}(6)$.

Second, familial affection has an important role to play in advancing living organ transplant. Showing love to the loved ones is the emotional basis for living organ transplant and is also the motivation for the living organ transplant(7). Li Yan (2007) randomly chose 600 residents from Henan province in China including Zhengzhou, Luoyang, Kaifeng and Nanyang to conduct a sample survey on people's attitude toward organ donation(8). Of the 600 respondents, 479 (80\%) were willing to donate their kidneys to their relatives as a result of familial affection, 73 (12\%) argued that they could not leave their relatives dead of organ failure, 48 (8\%) claimed that high moral standards motivated them to decide to donate their organs. It is clear that family affection is the main reason why people are willing to donate organs to their relatives in need.

Third, living organ transplant meets the beneficiary principle. The purpose of living organ transplant is to reduce the pain the patient suffers and rescue the patient's life. Compared to cadaveric organ transplant, living organ transplant is better for improving outcomes for organ recipients and quality of life in organ transplant recipients. Living organ transplant is to satisfy the wishes of both the donor and recipient and thus the integral effect can be achieved. As for living organ donation, donors act voluntarily and thus the harm to them is within the psychologically acceptable range; what benefits recipients most is to get their lives rescued(9).

Finally, the jurisprudential circle uses the donor's right to self-determination or the victim com- mitment to justify living organ donation. Tong (2005) claimed that the potential donor's and recipient's right to self-determination could be understood as the practice that they freely determine whether the transplant should be conducted and their families and medical professionals involved should fully respect their right of informed consent (8). Both the donor's and recipient's decision making on organ transplant must be out of their own wishes. Note that any decision influenced by actions such as intimidation and temptation, which violates the donor's and recipient's right to self-determination, cannot be regarded as independent decision. The so-called "victim commitments", also known as "victim's consent", indicates that the victims voluntarily renounce the relevant legal rights and interests protected by criminal law, and allow others to violate their own interests they give up voluntarily(10). Of course, both the right to self-determination and victim commitment have their boundaries. If the donor wants to end his/her life through organ donation, it should be forbidden. If the donation causes the donor any major health hazard or serious harm, the commitment will be invalid.

\section{The Solution to the Ethical Disputes of Living Organ Transplant}

Chen (2008) argued that living organ transplant was at the expense of fresh blood, pain, or even life(11). Whether in the past, present or future, at home or aboard, it is just an expedient method instead of the mainstream of organ transplant(11). Objectively speaking, procuring organs from living people is a reluctant action. It is a kind of helplessness. Huang (2014) reported that although living organ transplant is not encouraged by the state, we have no alternative but to do(12). He also stated that cadaveric organ donation should be encouraged and living organ donation as a kind of charitable behavior needs to be controlled(12). It is clear that the living organ transplant involves not only the ethical values, but also the ethical dilemmas. We argue that living organ transplant should be treated objectively rather than being absolutely forbidden, and it should be dealt with under the guiding principle on life ethics including voluntariness, gratuitousness and respect. In this sense, we propose three ideal approaches to solving the ethical 
disputes of the living organ transplant.

First, people should strengthen physical activity habit and prevent illness or disease actively. The Nationwide Body-building Program (20162020) issued by the State Council in June, 2016 claims that the national citizen's awareness about physical fitness will be improved markedly by 2020 , the number of people participating in physical fitness will increase obviously and the physical quality of the general public will be strengthened steadily. In addition, attention should be paid to the early diagnosis and treatment of the disease(13). For example, the liver cancer can be diagnosed and treated at an early stage, which is one of the most important approaches to improving the liver cancer survival rate.

Second, the government should encourage the citizens to donate their organs after death. Increasing cadaveric organ donation is the key to decreasing the number of living organ donation, which is the most effective approach to ethical dispute resolution of living organ transplant. In recent years, Chinese government has taken a range of measures to increase cadaveric organ donation. In 2013, with the support and supervision of the Red Cross Society of China, the organ donation online system and Chinese organ allocation and sharing system were launched, which could boost the donation rates and monitor the equitable distribution of donated organs(14). To better manage organ donation and transplantation, the committee of organ donation and transplantation was jointly established by the Red Cross Society of China (RCSC) and the National Health and Family Planning Commission (NHFPC) on March 7, 2014(14). As of December, 2015, there were in total 5734 cases of cadaveric organ donation in China, and 15,722 organs including liver, kidney, heart, lung and pancreas were donated(15). It indicates that more and more Chinese citizens are willing to donate their organs after death. With the gradual establishment of the social donation system and the rapid progress of the transplant technologies, the number of cadaveric organ donation will increase remarkably.

Third, new technologies should be developed for organ transplant. Recently, the researchers at Harvard University claimed that they were able to make some human tissues with blood vessels by $3 \mathrm{D}$ printing technology. Jennifer Lewis, the research team leader said: "we believe the progress we made today is vital, and I think it will eventually make artificial organs(16)". It is hoped that $3 \mathrm{D}$ printing technology can embed the blood vessel structure into the artificial organs, and these blood vessels will grow with other human tissues together. In October 2015, the world top journal Science reported that the gene of porcine endogenous retrovirus (PERV) can be successfully inhibited by using CRISPR/Cas9 gene editing technology (17). It indicates that human beings have made a great progress in the study of xenotransplants. However, there are still many barriers to overcome in the course of studying xenotransplants. After these technological difficulties are solved, the lack of available organs for transplant will cease.

\section{Two realistic approaches to ethical dispute resolution}

In recent years, the US and some European countries have strengthened the control of living organ transplant, and a number of scholars in these countries also raise various concerns about the living organ transplant. However, undeniably, as one of the important sources for organ transplant, the living organ transplant will continue to exist before other safe and effective alternative methods appear (e.g. allogeneic organ and artificial organ). Therefore, for the living organ transplant, what we need to do is to further standardize the living organ transplant and maintain the interests of both the donor and recipient (especially for the donor) in order to guarantee the moral acceptability of the living organ transplant. Thus, this paper proposes two realistic approaches to addressing the ethical disputes of the living organ transplant.

First, transplant professionals should obey the principle of choosing the lesser of the two evils and fulfil the wishes of both the donor and recipient when performing living organ transplant. If the living organ transplant is not performed, the patients will lose their life; however, if it is performed, the interests of the living donor will be violated. This poses actual ethical conflicts. It is thus necessary to find a comprising approach 
to this conflict resolution. We propose that performing the living organ transplant should be guided by the ethical principle of choosing the lesser of the two harms. In other words, living organ transplant should be supported as long as the quality of life of the living donor is not seriously affected and the recipient could benefit from the transplant. Therefore, we cannot consider that living organ transplant is not humanistic at all. Of course, Zhu's (2006) third reason for opposing the living organ transplant is very valuable. It should be acknowledged that to increase organ donation rates by encouraging the living organ donation is to put the cart before the horse. The living organ transplant is indeed a painful choice when there is no other alternative but to approve its performance.

Second, transplant professionals should reduce the harm to the donor as much as possible and try to improve the transplant quality. We do not fully agree with the Zhang's (2006) proposal that no one is allowed to rescue the lives of others by harming himself or herself, even if it is voluntary. The altruistic behavior is regarded as a noble action in the Chinese socio-cultural context(18). As a Buddhist saying goes, to save a life is better than building a seven-storeyed pagoda. At this point, the donors voluntarily renounce the relevant legal rights and interests protected by criminal law, and allow transplant professionals to violate them of their own free will. In this sense, the living organ donation cannot be fundamentally negated by the first reason for resistance to organ donation proposed by Zhu (2006), which just reminds us that we should protect the donor and try to reduce the possible harm to the donor. As a consequence, we should try to improve the transplant outcomes and guarantee the quality of life of the transplant recipient.

\section{Interpretation of the legal provisions on China's living organ transplant}

Regulations on Human Organ Transplant enacted in 2007 stipulate that the living donor should only be limited to the recipient's spouses, lineal relatives, and collateral relatives by blood up to the third degree of kinship or people who have proof of having kinship to the donor due to assistance or other reasons(19). It ensures that the potential living donor is the recipient's relative and thus would reduce the possibility of organ trading. It is well known that the living donation is harmful to the donor's health, and thus living organ donation will not occur unless there is deep affection and profound love between the donor and recipient. To better implement Regulations on Human Organ Transplantation, the Ministry of Health issued Several Provisions on Regulating Living Organ Transplantation in 2009, which made more detailed and definite provisions on the living organ transplant. Based on the ethical analysis above, we try to interpret these provisions.

\section{Voluntariness in informed consent}

Several Provisions on Regulating Living Organ Transplantation points out that a written consent to organ donation should be signed jointly by the donor and his/her family members including his/her parents, adult children and spouse if hel she has been married, and a written consent to the acceptance of the donor's organ should also be signed by the recipient. On one hand, these provisions highlight the voluntary and gratuitous principles of living organ donation with the aim of avoiding organ trafficking and also emphasize the informed consent of organ donors and their families to fully protect the donor's interests. One the other hand, these provisions ensure that the donor's decision is informed and free from coercion. The fundamental ethics principle for starting living organ donation is that the donors donate their organs of their own free will. Moreover, these provisions define the moral obligation of the transplant professionals in the course of performing the living organ transplant. Since the donation is of their own free will, donors have been psychologically prepared for the potential harm the transplant surgery may cause. At this point, the transplant specialists are only responsible for their own medical skills. Thus, the transplant professionals can avoid the violation of the moral principle of non-harmfulness and falling into the moral dilemma.

\section{A general medical evaluation}

Regulations on Human Organ Transplant stipulate that prior to conducting the living organ 
transplant, the medical institution and its medical practitioners involved in the living organ transplant should evaluate whether it is necessary for the recipient to receive the living organ transplant, whether the health status of the donor is suitable for organ donation and whether the removal of the potential donor's organ will influence his or her health status. It should be guaranteed that the physiological functions of the remaining organs will not be damaged by living organ donation. Strict attention must be given to preoperative assessment of living organ donor, which is one of the most fundamental conditions for conducting a smooth transplant surgery. Moreover, severe donor complications or donor death should be forbidden.

\section{Ethical review}

As the third party, the ethics committee takes the responsibility for making ethical evaluation of living organ transplant and has important role to play in ensuring the interests of the transplant professionals, donors, and recipients. Specifically, the ethics committee should fully review the authenticity and voluntariness of the donor's intention, the relationship between the donor and the recipient, and the appropriateness of the living organ transplant. The living organ transplant is a kind of high-risk surgery, which requires both sophisticated medical skills and strict ethics review. The primary responsibility of the ethics committee is to confirm the moral reasonableness of the living organ transplant. Thus, the ethical review has become a critical factor for determining whether living organ transplant can be ethically justified.

\section{Conclusion}

The living organ transplant is full of ethical dilemmas. It is an kind of reluctant action because of the lack of cadaveric donors. Thus, living organ transplant should be conducted under strict laws and regulations. Realistic approaches to addressing the ethical disputes of the living organ transplant include choosing the lesser of two evils, reducing the harm to the donor as much as possible and improving the transplant quality. Informed consent from the donor is the cornerstone of the living organ transplant. However, it is unknown to what extent donors are willing to donate their organs of their own free will instead of catering for their family interests. How to avoid turning "an act of great virtue" into "acting out of duty"? How to guarantee that the donor has sufficient psychological preparation and decision-making space instead of being forced by the family and social pressure? These issues are more complex, and we will explore them in another paper.

Contributorship Statement: Tongwei Yang was involved in writing the manuscript. Yijin Wu was the principal investigator and was involved in the conception of the idea and the design of this study.

\section{Competing interests: None.}

Funding: This study was funded by Shandong Social Science Council (CZXJ01).

Data sharing statement: No additional data are available. 


\section{References}

1. Lu D, Jiang J, Xu X. Organ Transplant Meeting Summary in 2012. Chinese Journal of Transplanation 2012; 6: 282-286.

2. Liu Y. The journey of a healthy liver -Observation to China' liver transplant. Heath Times. Available at: http://paper. people.com.cn/jksb/html/2011-01/20/content_728276.htm. Accessed January 20, 2011.

3. Dong H. Living organ transplant having more risks and causing irreversible damage to the donor. Available at: http://health. sohu.com/20121205/n359587806.shtml. Accessed December 5, 2011.

4. Zhang Z. The living organ donation should be stopped immediately. Medicine \& Philosophy 2006; 27: 62-63.

5. Zhu W. The Ethic Demonstration of Opposing the Living Organ Transplant. Chinese Medical Ethics 2006; 19: 7-10.

6. Wu H. The analysis on the psychological factor for the lack of organ donor. Journal of Clinical Rehabilitative Tissue Engineering Research 2008; 12: 3519-3522.

7. Wang H. The ethical review of the living organ transplant [D]. Guangxi Normal University; 2010.

8. Li Y. The survey on Henan residents' cognitive attitudes to the living organ transplant. Chinese Journal of Public Health 2007; 23: 758.

9. Tong X. The boundary of performing the right to self-determination during organ transplant. People's Procuratorial Monthly 2015; 23: 68-70.

10. Li X. The Study on the Criminal Issues of the Victim Commitment. Medicine and Jurisprudence 2016; 8 :17-22.

11. Chen Z. The living organ transplant being at the expense of fresh blood or even death. Available at: http://health.sohu. com/20081125/n260822912.shtml. Accessed November 25, 2008.

12. Huang J, Zhang S, Liu Y, et al. China organ donation and transplantation update: the Hangzhou Resolution. Hepatobiliary \& Pancreatic Diseases International 2014, 13: 122-124.

13. The Nationwide Body-building Program. Xinhua Net. Available at: http://news.xinhuanet.com/politics/201606/23/c_1119096945.htm. Accessed June 23, 2016.

14. Wu Y, Yang T, Li L, Ma W. Ethical issues relating to living organ donation in China. Transplantation Proceedings 2016 , 48: 1875-1878.

15. Ma X. The establishment of mechanism in humanitarian relief and giving thanks to the donor. Available at http://www. cn-healthcare.com/article/20151221/content-480557.html. Accessed December 21, 2015.

16. A big advance in medicine: $3 \mathrm{D}$ printing the human organ with blood vessel. $3 D$ ofweek.com

17. Available at http://3dprint.ofweek.com/2014-03/ART-132105-8130-28784917.html. Accessed March 7, 2014.

18. Xenotransplant. WOKEJI.COM. Available at http://h.wokeji.com/pl/kjjy/201512/t20151211_2030568.shtml. Accessed December 11, 2015.

19. Wu Y, Li L, Su H, Yao X, Ma W. Hospice and palliative care: development and challenges in China. Clinical Journal of Oncology Nursing 2016; 20: E16-20.

20. Huang J. Ethical and legislative perspective on liver transplantation in the People's Republic of China. Liver Transplant 2007; 13: 193-196.

Received: February 9, 2018

Accepted: April 3, 2018 